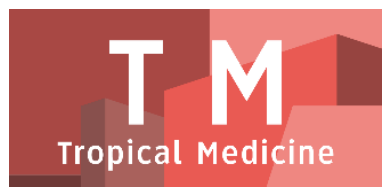

PAPER - OPEN ACCESS

\title{
Efektivitas Pemberian Temulawak Terhadap Dismenore Pada Remaja Di Smp Negeri 4 Tanjung Pura
}

\author{
Author : Siti Saidah Nasution \\ DOI $\quad: 10.32734 / \mathrm{tm} . v 1 \mathrm{i} 1.51$ \\ Paper Page : $24-31$
}

Volume 1 Issue 1 - 2018 TALENTA Conference Series: Tropical Medicine (TM)

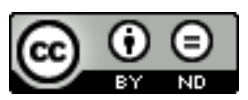

This work is licensed under a Creative Commons Attribution-NoDerivatives 4.0 International License.

Published under licence by TALENTA Publisher, Universitas Sumatera Utara
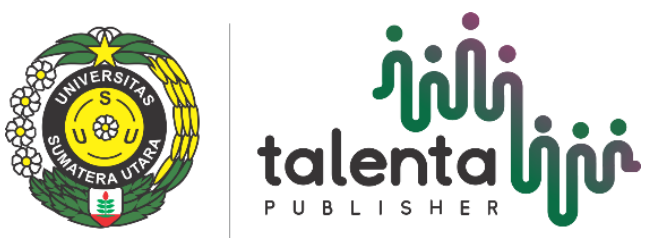


\title{
Efektivitas Pemberian Temulawak Terhadap Dismenore Pada Remaja Di Smp Negeri 4 Tanjung Pura
}

\author{
Siti Saidah Nasutionn ${ }^{\mathrm{a}, *}$, Dinda Alia Yessa ${ }^{\mathrm{a}}$ \\ ${ }^{a}$ Fakultas Keperawatan, Universitas Sumatera Utara, Medan 20155, Indonesia \\ saidah.nasution@yahoo.com
}

\begin{abstract}
Abstrak
Dysmenorrhea is one of the problems in the process of menstruation. Dysmenorrhea often occur in young children and can interfere with daily activities, such as does not concentration to learn, lazy follow extracurricular activities, can not attend school. For dysmenorrhea, pharmacological and nonpharmacological treatment is required. Handling nonpharmacological one of them by giving white turmeric. .The types this research is descriptive with Quasy Experiment design. This study was conducted to look at the effectiveness of white turmeric against a decrease in dysmenorrhea in adolescent in SMP Negeri 4 Tanjung Pura. The research places in SMP Negeri 4 Tanjung Pura. The research conducted October through June 2016 and the data collection was conducted from March to May 2016. The data analysis using statistical test of independent t-test. The research found effect of white turmeric against a decrease in dysmenorrhea pain in adolescents with pvalue 0.009 ( $p<0.05)$.
\end{abstract}

Kata Kunci: Dismenorey; Temulawak

\section{Pendahuluan}

Pubertas merupakan masa perkembangan remaja ditandai dengan matangnya organ-organ seksual. Seorang gadis memasuki masa pubertas biasanya mulai usia 10-14 tahun. Ketika mereka memasuki masa tersebut maka tubuh dan pikiran mereka juga berubah dan berkembang. Saat pubertas hormon LH (Luteinizing Hormone) dan FSH (Follicle Stimulating Hormone) akan terus meningkat. Peningkatan kadar hormon dapat merangsang pembentukan hormon seksual dan menyebabkan dimulainya menarche (menstruasi yang pertama).

Pada umumnya setiap perempuan akan merasakan nyeri ketika datangnya masa menstruasi. Nyeri ini dirasakan di pinggang, nyeri di perut, hingga nyeri di sekitar paha.Nyeri menstruasi adalah normal namun dapat berlebihan dirasakan masing-masing individu. Istilah dismenore (dysmenorrhoea) berasal dari bahasa Greek yaitu dys (gangguan atau nyeri hebat/abnormalitas), meno (bulan) dan rrhea yang artinya flow atau aliran [13]. Dismenore adalah nyeri kram perut atau ketidaknyamanan yang berhubungan dengan menstruasi [10].

Beberapa remaja perempuan yang menderita nyeri haid atau dismenore biasanya akan terganggu aktivitasnya sehingga mereka membatasi aktivitas harian mereka. Dismenore menyebabkan remaja perempuan tidak konsentrasi belajar, malas mengikuti kegiatan ektrakurikuler, bahkan tidak dapat hadir di sekolah seperti hari biasa sehingga pelajaran menjadi terganggu.

Umumnya ketidaknyamanan dimulai 1-2 hari sebelum menstruasi, namun nyeri yang paling berat selama 24 jam pertama menstruasi dan mereda pada hari kedua [12]. Sebagian remaja ada yang membutuhkan obat-obatan untuk mengurangi dismenore agar tetap dapat masuk sekolah seperti biasa.Namun sebagian remaja ada yang menghindari mengkonsumsi obat-obatan dikarenakan takut efek samping negatif dari penggunaan obat farmakologis. 
Sebenarnya dismenore juga dapat dikurangi dengan olahraga teratur sebelum masa menstruasi, kompres air hangat pada area yang nyeri serta menggunakan tumbuhan herbal seperti kunyit, temu putih, temulawak, dan lain sebagainya. Penelitian Kuntorini [9] dengan judul "Botani Ekonomi Suku Zingiberaceae sebagai Obat Tradisional Oleh Masyarakat di Kotamadya Banjarbaru", didapatkan hasil bahwa temulawak dimanfaatkan setelah persalinan oleh 30\% masyarakat Jawa dan 31,3\% masyarakat Banjar (Kalimantan Selatan) meskipun tujuannya adalah membersihkan darah nifas, melancarkan peredaran darah dan melancarkan haid. Dalam sebuah penelitian telah dilaporkan bahwa pada 8 sukarelawan sehat tidak ada efek samping setelahdosis oral 2 gram kurkumin [4] Penelitian oleh Devaraj, et all [3] dengan judul "Evaluation of the Antinoceptive Activity and Acute Oral Toxicity of Standardized Ethanolic Extract of The Rhizome of Curcuma xanthorrhiza Roxb", menemukan bawa ekstrak temulawak pada dosis 100mg/kg BB, $200 \mathrm{mg} / \mathrm{kg}$ BB, $400 \mathrm{mg} / \mathrm{kg}$ BB dengan metode formalin induced pain test mampu menunjukkan efek analgetik. Selanjutnya penelitian yang dilakukan Al-Tahan [1] dengan judul "Exploration of Antinociceptive, Antipyretic and Anti-inflammatory Activities of Curcumin in Male Rat", menyatakan bahwa kurkumin yaitu salah satu bahan aktif pada temulawak memiliki efek analgesik setelah dilakukan tes pada tikus.

Kemudian diperkuat oleh penelitian oleh Mahmood, Bachar, Islam, dan Ali [11] dengan judul "Analgesic and Diuretic Activity of Curcumaxanthorrhiza", mengatakan bahwa ekstrak methanol yang terdapat pada temulawak menunjukkan adanya efek analgesik pada percobaan yang dilakukan terhadap tikus.Prevalensi dismenore seluruh dunia mirip dengan yang di Amerika Serikat. Prevalensi dilaporkanberkisar dari 15,8\% menjadi 89,5\%, dengan tingkat yang lebih tinggi dilaporkan pada populasi remaja. Prevalensi kondisi ini diperkirakan $25 \%$ di antara wanita dewasa dan setinggi 90\% di kalangan remaja [2]. Sebuah penelitian di Australia pada gadis-gadis diSMA menemukan bahwa proporsi yang lebih tinggi, 93\% remaja melaporkan nyeri haid [8]. Hasil penelitian Pusat Informasi dan Konseling Kesehatan Reproduksi Remaja (PIK-KRR) di Indonesia tahun 2009 angka kejadian dismenore terdiri dari $72,89 \%$ dismenore primer dan $27,11 \%$ dismenore sekunder dan angka kejadian dismenore berkisar 45-95\% dikalangan perempuan usia produktif [13]. Berdasarkan hasil studi pendahuluan yang dilakukan peneliti dengan mencari data di UKS SMP Negeri 4 Tanjung Pura, didapatkan data sebanyak 28 siswi mengalami dismenore sepanjang Januari sampai Juni 2015. Siswi-siswi yang mengalami dismenoreakan beristirahat di UKS atau izin pulang kerumah jika nyeri yang dirasakan tidak tertahankan. Akibatnya, remaja yang menderita dismenore tidak belajar $100 \%$, mereka sering ketinggalan pelajaran, dan prestasi mereka menurun.

\section{Tujuan Penelitian}

Tujuan penelitian adalah untuk mengetahui efektivitas pemberian temulawak terhadap dismenore pada remaja.

\section{Metode Penelitian}

Penelitian ini menggunakan desain penelitian quasy experiment dengan rancangan penelitian Non Equivalent Control Group yang melibatkan dua kelompok, yaitu kelompok eksperimen dan kelompok kontrol. Sampel penelitian ini adalah 32 responden (16 kelompok ekperimen dan 16 kelompok kontrol) yang mengalami dismenore di SMP Negeri 4 Tanjung Pura. Kelompok intervensi akan diberikan temulawak ukuran 8,5 cm x $5 \mathrm{~cm}$ yang direbus, diberikan pagi dan sore pada hari 2 hari sebelum menstruasi sampai hari kedua menstruasi. Pengambilan sampel menggunakan total sampling. Analisa uji statistik melalui dua tahapan yaitu dengan menggunakan analisa univariat dan bivariat. Analisa univariat untuk mendapatkan gambaran tentang distribusi karakteristik responden seperti usia, usia pertama kali menstruasi (menarche), suku dan lain-lain. Analisa bivariat menggunakan uji non-parametrik yaitu t-independent test.

\section{Hasil Penelitian}

\subsection{Analisa Univariat}

Analisa univariat digunakan untuk mendapatkan data mengenai kaarakteristik responden, meliputi usia, usia pertama kali menstruasi (menarche), suku, makanan dan minuman yang biasa dikonsumsi, memiliki masalah dan jenis masalah yang dihadapi serta faktor yang mempengaruhi bertambahdan berkurangnya nyeri haid. 
Table. 1. Distribusi Frekuensi dan Presentase Berdasarkan Karakteristik Responden

\begin{tabular}{|c|c|c|}
\hline Karakteristik & $\mathrm{f}$ & $\%$ \\
\hline \multicolumn{3}{|l|}{ Usia Responden } \\
\hline Remaja Awal (11-14 tahun) & 16 & 50 \\
\hline Remaja Menengah (15-17 tahun) & 16 & 50 \\
\hline \multicolumn{3}{|l|}{ Usia Menarche } \\
\hline Remaja Awal (11-14 tahun) & 31 & 97 \\
\hline Remaja Menengah (15-17 tahun) & 1 & 3 \\
\hline \multicolumn{3}{|l|}{ Suku } \\
\hline Batak & 2 & 7 \\
\hline Jawa & 18 & 56 \\
\hline Minang & 1 & 3 \\
\hline Melayu & 11 & 34 \\
\hline \multicolumn{3}{|l|}{ Makanan } \\
\hline Gorengan & 9 & 28 \\
\hline Mie Instan & 6 & 19 \\
\hline Buah & 4 & 12 \\
\hline Sayur & 13 & 41 \\
\hline \multicolumn{3}{|l|}{ Minuman } \\
\hline Bersoda & 2 & 6 \\
\hline Dingin & 23 & 72 \\
\hline Kopi & 1 & 3 \\
\hline Teh & 6 & 9 \\
\hline \multicolumn{3}{|l|}{ Masalah } \\
\hline $\mathrm{Ya}$ & 21 & 66 \\
\hline Tidak & 11 & 34 \\
\hline \multicolumn{3}{|l|}{ Jenis Masalah } \\
\hline Ujian & 7 & 22 \\
\hline Tugas & 2 & 6 \\
\hline Masalah dengan Teman & 11 & 34 \\
\hline \multicolumn{3}{|l|}{ Faktor Memperberat Nyeri } \\
\hline Beraktifitas & 18 & 56 \\
\hline Tidak Beraktifitas & 14 & 44 \\
\hline \multicolumn{3}{|l|}{ Faktor Meringankan Nyeri } \\
\hline Minum Obat & 8 & 25 \\
\hline Tidur & 19 & 59 \\
\hline Minum Jamu & 5 & 16 \\
\hline
\end{tabular}

Berdasarkan tabel 1 umur responden paling besar adalah remaja awal dan remaja menengah sebanyak $50 \%$. Sebanyak 96,9\% responden menarche pada usia remaja awal. Menurut karakteristik suku sebagian besar suku Jawa 44\%.Makanan yang dikonsumsi responden sebanyak $41 \%$ adalah sayuran.Responden memilih minuman dingin sebanyak $72 \%$.Karakteristik responden yang memiliki masalah sebanyak $66 \%$, masalah yang paling banyak dialami 
adalah masalah dengan teman (37\%).Faktor yang memperberat nyeri haid responden adalah beraktivitas sebanyak $56 \%$.Faktor yang meringankan nyeri haid responden adalah tidur sebanyak $59 \%$.

Table. 2. Deskripsi Tingkat Nyeri Pretest Responden

\begin{tabular}{llll}
\hline \multicolumn{1}{c}{ Kelompok } & \multicolumn{2}{c}{ f } & \% \\
\hline Intervensi & 16 & 100 \\
Tidak Nyeri & 0 & 0 \\
Nyeri Ringan & 3 & 19 \\
Nyeri Sedang & 9 & 56 \\
NyeriBerat Terkontrol & 3 & 19 \\
Nyeri Berat Tidak Terkontrol & 1 & 6 \\
\hline Kontrol & 16 & 100 \\
Tidak Nyeri & 0 & 0 \\
Nyeri Ringan & 3 & 19 \\
Nyeri Sedang & 11 & 69 \\
Nyeri Berat Terkontrol & 2 & 12 \\
Nyeri Berat Tidak & 0 & 0 \\
Terkontrol & & \\
\hline
\end{tabular}

Berdasarkan tabel 2 bahwa variabel nyeri kelompok pretest pada kelompok intervensi paling dominan adalah nyeri sedang 9 responden $(56 \%)$.Variabel nyeri kelompok pretest pada kelompok kontrol paling dominan adalah nyeri sedang 11 responden (69).

Table. 3. Deskripsi Tingkat Nyeri Posttest Responden

\begin{tabular}{lcc}
\hline Kelompok & f & \% \\
\hline Intervensi & 16 & 100 \\
Tidak Nyeri & 12 & 13 \\
Nyeri Ringan & 10 & 62 \\
Nyeri Sedang & 3 & 19 \\
Nyeri Berat Terkontrol & 1 & 6 \\
Nyeri Berat Tidak Terkontrol & 0 & 0 \\
& & \\
Kontrol & 16 & 100 \\
Tidak Nyeri & 0 & 0 \\
Nyeri Ringan & 3 & 19 \\
Nyeri Sedang & 11 & 69 \\
Nyeri Berat Terkontrol & 2 & 12 \\
Nyeri Berat Tidak Terkontrol & 0 & 0 \\
\hline
\end{tabular}

Berdasarkan tabel 3 bahwa variabel nyeri kelompok posttest pada kelompok intervensi paling dominan adalah nyeri ringan 10 responden (62\%), nyeri. Variabel nyeri kelompok postest pada kelompok kontrol yang paling dominan adalah nyeri sedang 11 responden $(69 \%)$. 


\subsection{Analisa Bivariat}

Table. 4. Perbedaan Intensitas Nyeri Dismenore pada Kelompok Kontrol dan Kelompok Intervensi Sesudah Pemberian Temulawak

\begin{tabular}{|l|l|l|l|l|}
\hline Perbedaan Intensitas Nyeri & Mean & SD & P & N \\
\hline Intervensi & 2,7500 & 2,1756 & 0,009 & 16 \\
\hline Kontrol & 4,5000 & 1,2110 & & 16 \\
\hline
\end{tabular}

Rata-rata intensitas nyeri dismenore sesudah pemberian temulawak pada kelompok intervensi adalah 2,7500 dengan standar deviasi 2,1756 dan 4,5000 pada kelompok kontrol dengan standar deviasi 1,2110 tanpa pemberian temulawak. Hasil analisa diperoleh $\mathrm{p}(0,009)<\alpha(0,05)$, maka dapat disimpulkan ada perbedaan yang signifikan antara mean intensitas nyeri dismenore sesudah pemberian temulawak pada kelompok intervensi dan mean intensitas nyeri dismenore tanpa pemberian temulawak pada kelompok kontrol

\section{- Perbedaan Nyeri Sebelum dan Susudah pada Kelompok Intervensi}

Setelah dilakukan uji statistik paired t-test didapat hasil penelitian bahwa nilai rata-rata intensitas nyeri dismenore sebelum diberikan temulawak pada kelompok intervensi adalah 5,44 dengan standar deviasi 2,394 dan 2,75 setelah intervensi dengan standar deviasi 2,176. Perbedaan nilai mean pretest dan posttest pada kelompok intervensi adalah sebesar 2,69. Hasil analisa diperoleh $\mathrm{p}(0,000)<\alpha(0,05)$, maka dapat disimpulkan ada perbedaan yang signifikan antara mean intensitas nyeri dismenore sebelum dan sesudah diberikan temulawak pada kelompok intervensi.

- Perbedaan Nyeri Sebelum dan Sesudah pada Kelompok Kontrol I

Melalui hasil uji statistik didapatkan nilai rata-rata intensitas nyeri dismenore sebelum diberikan temulawak pada kelompok kontrol adalah 4,69 dengan standar deviasi 1,3022 dan 4,50 sesudah tanpa pemberian temulawak dengan standar deviasi 1,2111. Perbedaan nilai mean pretest dan posttest pada kelompok kontrol adalah sebesar 0,19 . Hasil analisa diperoleh $\mathrm{p}(0,08)>\alpha(0,05)$, maka dapat disimpulkan tidak terdapat perbedaan yang signifikan antara mean intensitas nyeri dismenore sebelum dan sesudah diberikan temulawak pada kelompok kontrol.

\section{Pembahasan}

\subsection{Gambaran Intensitas Nyeri Dismenore pada Kelompok Intervensi}

Berdasarkan hasil penelitian pada kelompok intervensi, responden yang mengalami nyeri berat tidak terkontrol setelah diberi temulawak berubah menjadi nyeri berat terkontrol.Responden yang mengalami nyeri berat terkontrol setelah diberi temulawak berubah menjadi nyeri sedang.Responden yang mengalami nyeri sedang setelah diberi temulawak berubah menjadi nyeri ringan.Dan responden yang mengalami nyeri ringan setelah diberi temulawak berubah menjadi tidak merasakan nyeri.Usiamenarche responden pada kelompok intervensi cenderung lebih banyak 12 tahun bukan < 12 tahun sehingga hal ini mendukung intervensi pemberian temulawak dikarenakan menurut teori Proverawati [13] yaitu hormon gonadtropin diproduksi sebelum anak usia 8 tahun. Hormon gonadtropin ini mempercepat terjadinya menstruasi dini sehingga dapat menimbulkan nyeri atau kram otot dibagian abdomen ketika menstruasi.

Rasa nyeri itu disebabkan karena anatomi reproduksi belum berfungsi secara optimal dan belum siap mengalami perubahan-perubahan fungsi dari organ reproduksi itu sendiri.Penurunan tingkat nyeri pada kelompok intervensi ini juga didukung oleh jenis makan yang biasa di konsumsi oleh responden kelompok intervensi yaitu sebagian besar lebih suka memakan sayur. Diet yang adekuat pada remaja adalah diet yang bervariasi dan seimbang, meliputi cukup karbohidrat, protein, lemak, vitamin, mineral dan air.

Dengan diet yang adekuat maka status gizi remaja putri akan baik, maka akan tercapai derajat kesehatan maksimal, fungsi hormon estrogen dan progesterone maksimal, akan terhindar dari premenstruasi syndrome dan keluhan nyeri haid. Pada kelompok intervensi, sebagian besar responden sangat senang diberikan temulawak karena tingkat nyeri yang dirasakan menurun.Sebelum diberikan intervensi, biasanya responden memilih untuk tidak beraktivitas karena jika mereka beraktivitas hal itu menyebabkan nyeri bertambah parah. 


\subsection{Gambaran Intensitas Nyeri Dismenore pada Kelompok Kontrol}

Berdasarkan hasil penelitian pada kelompok kontrol, responden yang mengalami nyeri berat terkontrol setelah tanpa pemberian temulawak tetap mengalami nyeri berat terkontrol.Responden yang mengalami nyeri sedang setelah tanpa pemberian temulawak tetap mengalami nyeri sedang.Dan responden yang mengalami nyeri ringan setelah tanpa pemberian temulawak tetap mengalami nyeri ringan.

Usia menarche responden pada kelompok kontrol cenderung lebih banyak 11 tahun dan 12 tahun. Hal ini tidak mendukung intervensi pemberian temulawak karena usiamenarche dibawah 12 tahun lebih besar kemungkinana menderita dismenore.Hal ini juga selaras dengan hasil penelitian Hasrinta dan Pajeriaty [5] yang menyimpulkan bahwa terjadinya dismenore disebabkan oleh remaja yang mengalami menarche $<12$ tahun. Diperkuat oleh teori Proverawati (2009) yang mengatakan menarche dini ( $<12$ tahun) adalah terjadinya menstruasi sebelum umur 12 tahun yang dikarenakan pubertas dini dimana hormon gonadtropin diproduksi sebelum anak usia 8 tahun. Hormon gonadtropin ini mempercepat terjadinya menstruasi dini sehingga dapat menimbulkan nyeri atau kram otot dibagian abdomen ketika menstruasi.

Rasa nyeri itu disebabkan karena anatomi reproduksi belum berfungsi secara optimal dan belum siap mengalami perubahan-perubahanfungsi dari organ reproduksi itusendiri. Pada kelompok kontrol responden banyak berasal dari suku Melayu dimana suku Melayu menyukai makanan manis. Hal ini selaras dengan minuman yang paling banyak dipilih responden yaitu minuman bersoda.Minuman bersoda mengandung natrium tinggi, dimana minuman atau makanan yang mengandung natrium tinggi adalah makanan sampah. Salah satu penyebab kebiasaan makan yang salah pada remaja adalah pengetahuan gizi yang rendah. Pengetahuan dan praktek gizi remaja yang rendah tercermin dari perilaku menyimpang dalam kebiasaan memilih makanan. Remaja yang memiliki pengetahuan gizi yang baik akan lebih mampu memilih makanan yang sesuai dengan kebutuhanya. Kebiasaan makan remaja ini akan berpengaruh saat mereka menstruasi. Karena ada makanan-makanan tertentu yang dapat memperberat rasa nyeri saat haid.

Hal lain yang menyebabkan skala nyeri pada kelompok kontrol tetap di skala yang sama didukung oleh faktor kejiwaan. Pada penelitian ini, responden kelompok kontrol yang memeliki masalah sebanyak $75 \%$. Hal ini sejalan dengan penelitian Hasrinta dan Pajeriaty [5] bahwa 40\% responden penelitiannya yang mengalami stress merasakan nyeri dismenorekarena terdapat hubungan antara stres dengan kejadian dismenore. Ju, Jones \& Mishra [8] melaporkan bahwa positif adanya hubungan antara stres dan risiko dismenore.

\subsection{Efektivitas Pemberian Temulawak terhadap Penurunan Dismenore}

Berdasarkan penelitian yang telah dilakukan di SMP Negeri 4 Tanjung Pura, maka didapatkan hasil uji statistik dengan menggunakan uji independent t-test diperoleh $\mathrm{p}(0,009)$ berada di daerah penolakan H0 maka H0 ditolak. Hal ini berarti terdapat perbedaan antara mean intensitas nyeri dismenore pada kelompok intervensi setelah pemberian temulawak dan pada kelompok kontrol tanpa pemberian temulawak sehingga dapat disimpulkan bahwa pemberian temulawak dapat menurunkan intensitas nyeri dismenore.

Dari sebaran data kontrol dan intervensi juga dapat dilihat bahwa rata-rata nyeri yang dirasakan responden tanpa pemberian temulawak adalah nyeri sedang.Sedangkan responden yang diberikan temulawak pada juga pada rentang nyeri sedang. Melalui keterangan tersebut dapat dilihat bahwa terjadi penurunan rata-rata intensitas nyeri dismenore sesudah pemberian temulawak (posttest) pada kelompok intervensi sedangkan pada kelompok kontrol tidak terjadi penurunan rata-rata intensitas nyeri dismenore (posttest) secara signifikan tanpa pemberian temulawak. Rata-rata intensitas nyeri dismenore pada kelompok intervensi mengalami penurunan sebanyak 2,69 poin. Sedangkan rata-rata intensitas nyeri dismenore pada kelompok kontrol mengalami penurunan sebanyak 0,19 poin.

Rata-rata intensitas nyeri dismenore kelompok intervensi pada pretest dan posttest menurun dikarenakan pemberian temulawak, dimana menurut Info Pengawas Obat dan Makanan [7] tentang gerakan nasional minum temulawak, dijelaskan bahwa kurkumin yang terkandung dalam temulawak mempunyai aktivitas anti radang yang setara dengan 100mg fenilbutazon yang dapat berguna mengurangi nyeri. Aktivitas ini dapat dicapai melalui penghambatan pembentukan serta transportasi mediator yaitu prostaglandin. Sementara itu pada kelompok kontrol 
pada pretest mupun posttest tidak diberikan intervensi apapun sehingga intensitas nyeri dismenore responden cenderung tetap di skala yang sama.

Penelitian ini sejalan dengan hasil yang diperoleh oleh Hayani [6] yang menyatakan bahwa didalam temulawak terdapat kandungan minyak atsiri dan pati masing-masing 3,81\% dan 41,45\% yang telah diketahui dapat mengurangi rasa nyeri. Berdasarkan penelitian tersebut pemberian temulawak akan lebih efektif jika disajikan dalam bentuk jamu. Kemudian diperkuat denganpenelitian lain yang dilakukan oleh Rakhma [14] menemukan bahwa upaya penanganan dismenore dengan cara nonfarmakologi yang dilakukan oleh siswi Sekolah Menengah Kejuruan (SMK) Arjuna Depok sebagian besar meminum obat herbal sebanyak 51 responden $(39,5)$. Oleh karena itu disimpulkan bahwa pemberian temulawak pada saat menstruasi dapat mengurangi rasa nyeri. Beberapa penelitian membuktikan bahwa ekstrak temulawak mengandung kurkumin [6].

Data menurut Info Pengawas Obat dan Makanan terdapat tujuh kegunaan temulawak pada masyrakat yaitu memperbaiki nafsu makan, memperbaiki fungsi pencernaan, memelihara kesehatan fungsi hati, mengurangi nyeri dan radang sendi, menurunkan lemak darah, antioksidan untuk menjaga kesehatan, dan membantu menghambat penggumpalan darah. Penelitian ini juga selaras dengan penelitian yang dilakukan oleh Kuntorini [9] dengan judul "Botani Ekonomi Suku Zingiberaceae sebagai Obat Tradisional Oleh Masyarakat di Kotamadya Banjarbaru", didapatkan hasil bahwa temulawak dimanfaatkan setelah persalinan oleh 30\% masyarakat Jawa dan 31,3\% masyarakat Banjar (Kalimantan Selatan) meskipun tujuannya adalah membersihkan darah nifas, melancarkan peredaran darah dan melancarkan haid.

Mengkonsumsi temulawak dapat menurunkan intensitas nyeri dismenore. Temulawak diketahui mengandung senyawa kimia yang mempunyai keaktifan fisiologi, yaitu kurkuminoid dan minyak atsiri. Kurkuminoid mempunyai aroma yang khas, tidak toksik. Selain itu temulawak juga memiliki beragam kandungan fitokimia yaitu alkaloid dimana contoh senyawa alkaloid adalah morfin yang berfungsi sebagai analgesik sehingga nyeri yang dirasakan pada saat menstruasi dapat berkurang dengan mengkonsumsi temulawak. Kesimpulan menerima Ha yaitu ada pengaruh pemberian temulawak terhadap penurunan nyeri dismenore pada remaja. Nilai t negatif memberi makna bahwa rata-rata nilai kelompok intervensi lebih rendah dibanding nilai rata-rata kelompok kontrol. Dengan jumlah data sebanyak 16 responden dengan nilai ketelitian $\alpha=0,05$. Dengan demikian penelitian ini dapat disimpulkan bahwa pemberian temulawak dapat menurunkan intensitas nyeri dismenore.

\section{Kesimpulan}

- Nyeri haid pada kelompok intervensi sebelum diberi temulawak paling dominan adalah nyeri sedang, setelah diberi temulawak nyeri haid yang paling dominan adalah nyeri ringan.

- Nyeri haid pada kelompok kontrol sebelum diberi temulawak paling dominan adalah nyeri sedang, setelah tanpa pemberian temulawak nyeri haid yang paling dominan adalah nyeri sedang.

- Terdapat pengaruh pemberian temulawak terhadap penurunan nyeri dismenore pada anak remaja dengan $p$ Value $0,009(\mathrm{p}<0,05)$.

\section{Referensi}

[1] Al-Tahan, F. J. (2012) "Exploration of antinociceptive, antipyretic and anti-inflammatory activities of Curcumin in male rat". Iraqi Journal of Science.786-79

[2] Calis, K. A. (2014) "Dysmenorrhea". http://emedicine.medscape.com/article/253812 _overview\#a6 diakses pada 9 Oktober 2015

[3] Devaraj, S., Esfahani, A. S., Ismail, S., Ramanathan, S., \& Yam, M. F. (2010) "Evaluation of The Antinoceptive Activity and Acute Oral Toxicity of Standardized Ethanolic Extract of The Rhizome of Curcuma xanthorrhiza Roxb". Journal of Molecules. 15:2925-2934

[4] Galen, E. V., \& Kroes, B. (2014) "Assesment report on Curcuma xanthorrhiza Roxb.(C.xanthorrhiza D. Dietrich), rhizome”. European Medicines Agency: United Kingdom

[5] Hasrinta \& Pajeriaty. (2014) "Faktor yang Berhubungan dengan Kejadian Dismenore pada Siswi di SMA Negeri 21 Makassar". http://www.library.stikesnh.ac.id diakses pada Oktober 2015

[6] Hayani, E. (2008) “Analisis Kandungan Kimia Temulawak”. http://balitnak.litbang.pertanian.go.id diakses pada desember 2015

[7] Info POM. (2005) "Gerakan Nasional Minum Temulawak". Badan POM RI

[8] Ju, H., Jones, M., \& Mishra, G. (2013) "The Prevalence and Risk Factors of Dysmenorrhea”. http://epirev.oxfordjournals.org/ diakses pada 27 Oktober 2015 
[9] Kuntorini. E. M. (2005) "Botani Ekonomi Suku Zingiberaceae sebagai Obat Tradisional oleh Masyarakat di Kotamadya Banjarbaru". Journal of Bioscientiae, 2(1): 25-36.

[10]Lewis, S. L., Dirksen, S. R., Heitkemper, M. M., \& Bucher, L. (2014) "Medical-Surgical Nursing 9th Edition Assesment and Management of Clinical Problems". St. Louis: Elsavier Mosby

[11] Mahmood, M. H., Bachar, S. C., Islam , M. S., \& Ali, M. S. (2004) “Analgesic and Diuretic Activity of Curcuma xanthorrhiza”. Dhaka University Journal of Pharmaceutical Sciences. 3:1-2

[12]Morgan, G. \& Hamilton, C. (2009) "Buku Saku Obstetri dan Ginekologi”. Jakarta: EGC

[13]Proverawati, A. \& Misaroh, S. (2009) "Menarche Menstruasi Pertama Penuh Makna". Yogyakarta: Numed

[14]Rakhma, A. (2014) "Gambaran Derajat Dismenore dan Penangannya pada Siswi SMK Arjuna Depok Jawa Barat". http://repository.uinjkt.ac.id/ dspace/handle/123456789/24158 diakses pada 20 Oktober 2015 